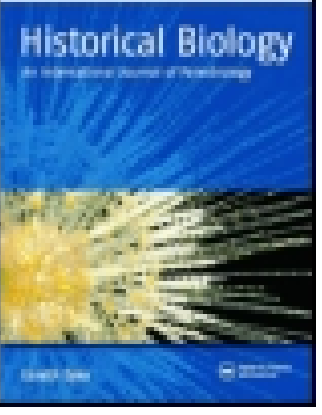

Historical Biology

An International Journal of Paleobiology

ISSN: 0891-2963 (Print) 1029-2381 (Online) Journal homepage: http://www.tandfonline.com/loi/ghbi20

\title{
A new species of Panochthus Burmeister (Xenarthra, Cingulata, Glyptodontidae) from the Pleistocene of the Eastern Cordillera, Bolivia
}

\author{
Alfredo Eduardo Zurita, Martín Zamorano, Gustavo Juan Scillato-Yané, \\ Sergio Fidel, Martín Iriondo \& David D. Gillette
}

To cite this article: Alfredo Eduardo Zurita, Martín Zamorano, Gustavo Juan Scillato-Yané, Sergio Fidel, Martín Iriondo \& David D. Gillette (2017): A new species of Panochthus Burmeister (Xenarthra, Cingulata, Glyptodontidae) from the Pleistocene of the Eastern Cordillera, Bolivia, Historical Biology, DOI: 10.1080/08912963.2016.1278443

To link to this article: http://dx.doi.org/10.1080/08912963.2016.1278443

曲 Published online: 16 Jan 2017.

Submit your article to this journal $₫$

山 Article views: 5

Q View related articles $\sqsubset$

View Crossmark data $\nearrow$ 


\title{
A new species of Panochthus Burmeister (Xenarthra, Cingulata, Glyptodontidae) from the Pleistocene of the Eastern Cordillera, Bolivia
}

\author{
Alfredo Eduardo Zurita ${ }^{a}$, Martín Zamorano ${ }^{b}$, Gustavo Juan Scillato-Yanéb, Sergio Fidelc ${ }^{c}$, Martín Iriondo and David D. \\ Gillette
}

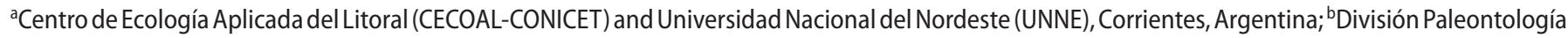
de Vertebrados, Museo de La Plata, Facultad de Ciencias Naturales y Museo, Universidad Nacional de La Plata, La Plata, Argentina; ‘Museo Universitario "Ricardo Bohorquez", Potosí, Bolivia; 'Consejo Nacional de Investigaciones Científicas y Técnicas, Facultad de Ingeniería y Ciencias Hídricas (Universidad Nacional del Litoral), Ciudad Universitaria, Santa Fe, Argentina; ${ }^{e}$ Museum of Northern Arizona, Flagstaff, AZ, USA

\begin{abstract}
Panochthus and Glyptodon are the Pleistocene Glyptodontidae having the greatest range of latitudinal distribution and elevation in South America. The most recent revisions of Panochthus recognized its high taxonomic diversification mainly distributed in the Chaco-Pampean region of Argentina, Uruguay, southern Bolivia and southern and north-eastern Brazil, while the Andean records are poorly known. This contribution aims: (a) to describe a new species of Panochthus from the Pleistocene of the surroundings of Potosi (Bolivia), which represents one of the highest known elevation records for fossil Xenarthra; (b) to carry out a phylogenetic analysis in order to test its location in Panochthus and relationship to some allied genera; (c) to discuss some palaeobiogeographical and morphological implications. The results show that, in agreement with previous studies, Panochthus is a natural group, being Propanochthus the sister taxa. This conclusion agrees, at least in part, with the original interpretation of Burmeister, who recognized Pr. bullifer as belonging to Panochthus. The genera Nopachtus and Phlyctaenopyga are more closely related to some 'Plohophorini' than to the clade Propanochthus + Panochthus. Within Panochthus, this new species occupies a relatively basal position as a sister taxon of the clade composed of $P$. tuberculatus, $P$. intermedius, and P. greslebini.
\end{abstract}

\section{ARTICLE HISTORY}

Received 15 September 2016 Accepted 30 December 2016

\section{KEYWORDS}

Panochthus; morphology; South America; phylogeny; diversity; Glyptodontidae

\section{Introduction}

Xenarthra represents one of the four major clades of Placentalia, probably the only clade to originate in South America (Pascual 2006; Gaudin \& Croft 2015; Superina \& Loughry 2015). Even though the diversity of modern xenarthrans is restricted to approximately 31 species (Abba et al. 2012), they were one of the most diversified groups during most of the Cenozoic (Marshall \& Cifelli 1990; McKenna \& Bell 1997). Within Xenarthra, the family Glyptodontidae (Late Eocene-Early Holocene) constituted a conspicuous clade of large armoured herbivores, achieving an evident diversification during some intervals and reaching Central and North America as part of the Great American Biotic Interchange during the Pliocene (Carlini \& Zurita 2010; Woodburne 2010; Gillette et al. 2016).

In the last decades, knowledge of taxonomic and phylogenetic aspects of South American Glyptodontidae have been largely improved, especially in Neogene and Quaternary taxa from the Patagonian and Pampean regions of Argentina (Fernicola 2008; González Ruiz 2010; Soibelzon et al. 2010; González Ruiz et al. 2011; Cruz et al. 2016; Mitchell et al. 2016), western Uruguay (Perea 2005), southern Bolivia (Zurita et al. 2009), and Brazil (Oliveira et al. 2010; Porpino et al. 2010, 2014). In addition, during the past two decades there has been an increase in the knowledge of the diversity of Glyptodontidae from areas of South America where they were poorly known. This is especially evident in the extra-patagonian region in Chile (Croft et al. 2007), and from middle and low latitudes of South America, such as Quebrada Honda (Frailey 1988) and Cochabamba (Zurita, Zamorano, et al. 2011) in Bolivia, western Brazil (Cozzuol 2006; Tejada-Lara et al. 2015), Peru (Pujos \& Salas 2004), Colombia (Carlini et al. 1997; Zurita et al. 2012, 2013), and Venezuela (Carlini, Zurita et al. 2008, Carlini, Zurita, Scillato-Yané et al. 2008; Carlini \& Zurita 2010; Zurita, Carlini, et al. 2011).

Concerning the distribution of Quaternary Glyptodontidae in South America (see Carlini \& Scillato-Yané 1999), only the genera Glyptodon Owen and Panochthus Burmeister have been reported in Andean and sub-Andean regions (Hoffsfetter 1970; Pujos \& Salas 2004; Zurita et al. 2009; Zurita, Zamorano, et al. 2011, 2012, Zurita et al. 2016). Panochthus has the most extensive latitudinal distribution, from southern Argentina $\left(47^{\circ} 01^{\prime} \mathrm{S}\right.$ $\left.67^{\circ} 14^{\prime} \mathrm{W}\right)$ to northeastern Brazil $\left(05^{\circ} 11^{\prime} \mathrm{S} 39^{\circ} 17^{\prime} \mathrm{W}\right)$, and its taxonomy and phylogeny have been recently updated (Soibelzon et al. 2010; Cruz et al. 2011; Zamorano 2012; Zamorano \& Brandoni 2013; Porpino et al. 2014; Zamorano et al. 2014). 
Table 1. Linear measurements (in $\mathrm{mm}$ ) of Panochthus hipsilis, $P$. intermedius and $P$. tuberculatus.

\begin{tabular}{lccc}
\hline & $\begin{array}{c}\text { P. hipsilis (MURB } \\
\text { 1906A) }\end{array}$ & $\begin{array}{c}\text { P. tuberculatus } \\
(\text { MLP 16-29) }\end{array}$ & $\begin{array}{c}\text { P. intermedius } \\
(\text { MHNC 13491) }\end{array}$ \\
\hline SKULL & & & \\
TL & 390 & 400 & 420 \\
MDZA & & 320 & 310 \\
TDPR & & 212 & 214 \\
ID & 236 & 197 & 196 \\
MTDRA & 155 & 211 & 214 \\
TDNA & 75 & 89 & 118 \\
DVDNA & 270 & 66 & 79 \\
LP & 212 & 293 & 201 \\
LTR & $1906 \mathrm{~B}$ & 246 & 1900 \\
CARAPACE & MURB & 2030 \\
TL & 1270 & 1720 & \\
APLDC & 1460 & 1770 & MLP 16-36 \\
C. TUBE & & MLP 16-31 & \\
TL & 640 & 900 & \\
\hline
\end{tabular}

Abbreviations: APLDC, antero-posterior length along dorsal curvature; DVDNA, dorso-ventral diameter of narial aperture; ID, interorbital diameter; LP, length of palate; LTR, length of tooth rows; MDZA, maximum diameter between zygomatic arches; Mf, mf, upper and lower molariforms, respectively; MTDRA, maximum transverse diameter of rostral area between lacrimals; TDPR, transverse diameter of postorbital region; TDNA, transverse diameter of narial aperture; TL, tota length.

Panochthus seems to be one of the most diversified genera among Quaternary Glyptodontidae, being frequently recorded in Pleistocene sediments of Argentina, Brazil, and Uruguay, whereas the records in Paraguay and Bolivia are much more scarce (Báez-Presser et al. 2004; Zurita et al. 2009; Zurita, Zamorano, et al. 2011). The following species can be recognized: P. intermedius and P. subintermedius (Early PleistoceneMiddle Pleistocene); P. tuberculatus and P. frenzelianus (Middle Pleistocene-Late Pleistocene); P. greslebini and P. jaguaribensis can only be referred to the Pleistocene sensu lato. These latter two species were interpreted as endemics of the Brazilian Intertropical Region (sensu Cartelle 1999) (Porpino et al. 2014, but see Zamorano et al. 2015).

The cladistic status of the tribe Panochthini (Late MiocenePleistocene), which traditionally included the genera Panochthus, Propanochthus and Nopachtus (see Hoffstetter 1958; Paula 1979) has been tested recently. The phylogenetic analyses indicate the condition of a non-natural group of Panochthini because the latter two genera (Propanochthus and Nopachtus) seem to be more related to some species of 'Plohophorini' than to Panochthus (Zamorano \& Brandoni 2013). Although there is a consensus about the monophyly of Panochthus and the condition of a non-natural group of the tribe, the relationship of the species within Panochthus and allied genera (i.e. Propanochthus and Nopachtus) is still controversial (see Zamorano \& Brandoni 2013; Porpino et al. 2014).

This contribution aims: (a) to describe a new species of Panochthus from the Pleistocene of the Eastern Cordillera of the surroundings of the locality of Potosí, Bolivia, which, in turn, constitutes one of the highest known elevation records for fossil Xenarthra ( $4000 \mathrm{~m})$; (b) to carry out a cladistic analysis in order to test its phylogenetic position within Panochthus and allied genera; and (c) to discuss some palaeobiogeographical and morphologic aspects of the Pleistocene Glyptodontidae in South America, with emphasis in the high elevation glyptodonts from the Andean and sub-Andean regions of Bolivia.

\section{Materials and methods}

The chronological and biostratigraphic schemes used here correspond to those proposed by Cione and Tonni (2005) and (Soibelzon et al. 2008). The systematics arrangement partially follows Hoffstetter (1958), Paula (1979), McKenna and Bell (1997), and Zamorano et al. (2014). All the values included in tables are expressed in millimeters $(\mathrm{mm}$ ), with an error range of $0.5 \mathrm{~mm}$, and are provided in Table 1. Measurements smaller than $150 \mathrm{~mm}$ were taken with 'vernier' calipers; measurements greater than this value were taken using an anthropometric spreading caliper. The description and terminology for osteoderms follow mainly Zurita (2007), Krmpotic et al. (2009), and González Ruiz et al. (2015) for molariforms. The dorsal carapace was divided into the regions recognized by Cruz et al. (2011) and Porpino et al. (2014). The referred materials belonging to the species of Panochthus (including the type materials) and related species used for comparative and cladistic purposes are listed in Appendix 1, as well as the main references. Details on the cladistic analysis used in this contribution are given in the Phylogenetic Analysis section. Appendix 2 shows the character and character states used in the cladistic analysis. Appendix 3 includes the character-taxon matrix used in the cladistic analysis.

Institutional abbreviations. AMNH, American Museum of Natural History, New York, USA; Ctes-PZ, Paleozoología Corrientes, Facultad de Ciencias Exactas and Naturales and Agrimensura, Universidad Nacional del Nordeste, Corrientes, Argentina; MACN-Pv, Colección Nacional de Paleontología de vertebrados del, Museo Argentino de Ciencias Naturales 'Bernardino Rivadavia', Buenos Aires, Argentina; MCA, Museo de Ciencias Naturales 'Carlos Ameghino', Mercedes, Buenos Aires, Argentina; MHNS, Museo de Historia Natural de Sucre, Bolivia; MLP, División Paleontología Vertebrados, Facultad de Ciencias Naturales and Museo, Universidad Nacional de La Plata, Argentina; MHNC, Museo de Historia Natural de Cochabamba 'Alcide d'Orbigny', Bolivia; MP, Museo de Puna (Puna) Potosí, Bolivia; MPAC, Museo Paleontológico Real de San Carlos 'Armando Calcaterra', Colonia, Uruguay; MPH, Museo Municipal 'Punta Hermengo', Miramar, Buenos Aires, Argentina; MUFyCA, Museo Universitario 'Florentino y Carlos Ameghino', Universidad Nacional de Rosario, Argentina; MURB, Museo Universitario 'Ricardo Bohorquez', Potosí, Bolivia; USNM, National Museum of Natural History, Smithsonian Institution, Washington, D. C., USA.

Other abbreviations. LT, tree length; RI, retention index; CI, consistency index; MPT, most parsimonious tree; Ma, million years; masl, meters above sea level.

\section{Systematic paleontology}

Magnorder Xenarthra Cope 1889

Order Cingulata Illiger 1811

Suborder Glyptodontia Ameghino 1889

Superfamily Glyptodontoidea Gray 1869

Family Glyptodontidae Gray 1869

Tribe Hoplophorini Huxley 1864

Genus Panochthus Burmeister 1866

Panochthus hipsilis n. sp.

(Figures 1 and 2) 
(a)

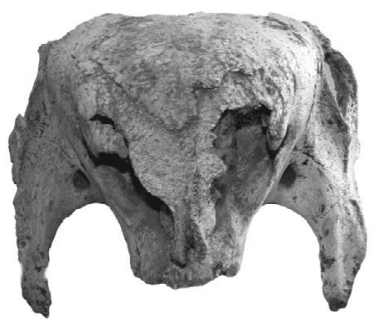

(c)

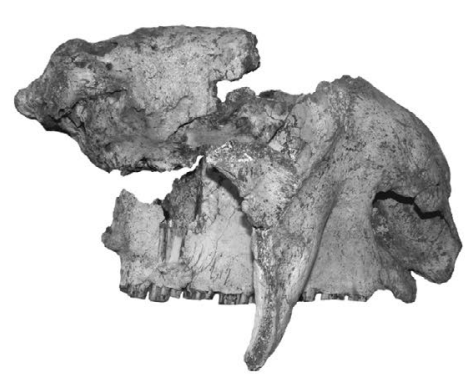

(b)

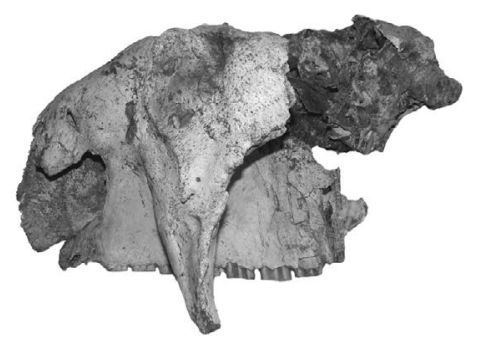

(d)

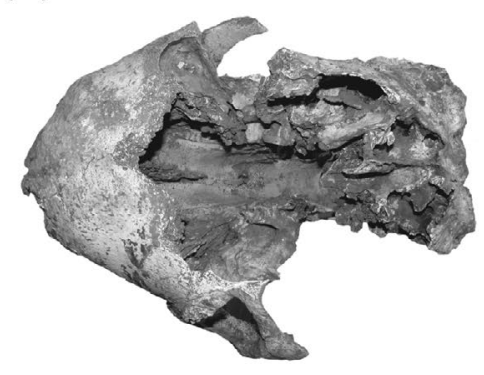

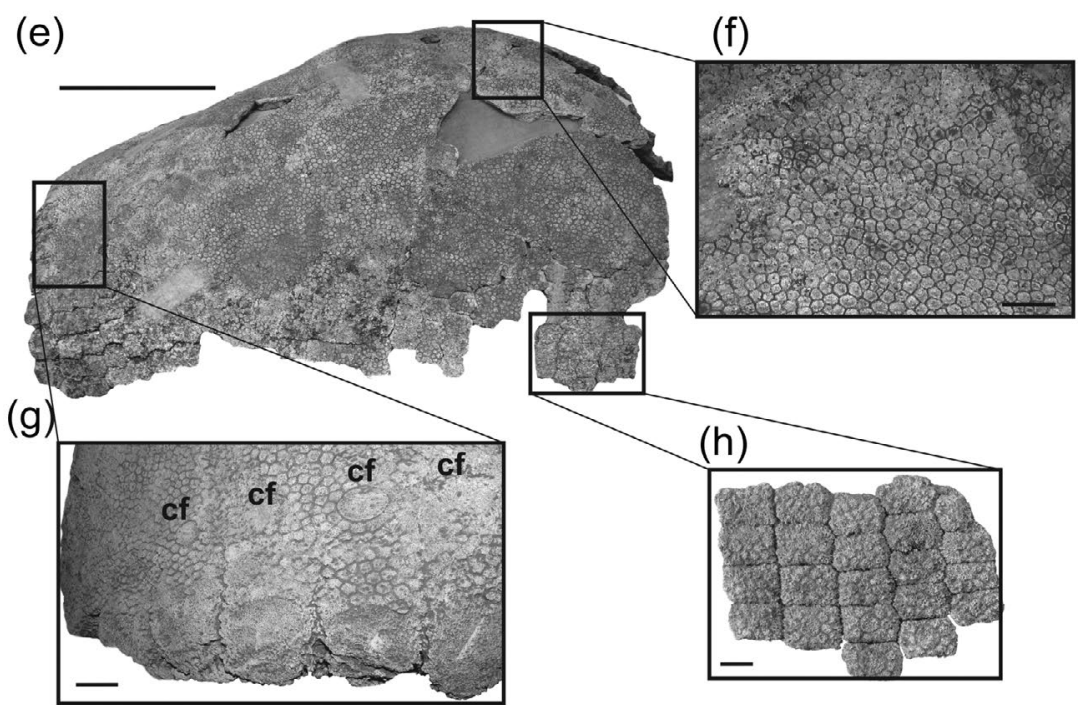

Figure 1. Panochthus hipsilis. (A)-(D) MURB 1906A. Skull in frontal, right, left and dorsal views. Scale bar is $100 \mathrm{~mm}$. MURB 1906B. (E) dorsal carapace in lateral view. Scale bar is $300 \mathrm{~mm}$; (F) detail of the anterior region showing the reticular ornamentation pattern; $\mathbf{G}$, detail of the posterior region showing the central figures (cf); $(\mathrm{H})$ detail of the lateral region.

Note: Scale bars in F, G and $\mathrm{H}$ are $20 \mathrm{~mm}$.

Holotype: MURB 1906A (a partial skull) and MURB 1906B (dorsal carapace almost complete including several fragments of associated osteoderms belonging mostly to the lateral region; two vertebrae and other indeterminate remains).

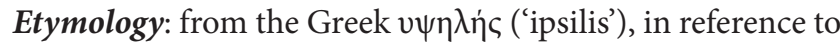
the high elevation where this new species was found.

Type locality: near the city of Potosi (Bolivia), approximately $13 \mathrm{~km}$ to the northeast, following the route 5 to Sucre ( $c a .19^{\circ}$ $29^{\prime} \mathrm{S}-65^{\circ} 41^{\prime} \mathrm{W}$ ) (Figure 3).

Referred material: MHNS 8, caudal tube.

Comments: The caudal tube is referred to Panochthus hipsilis according to the following evidence: (a) the geologic and paleontological information suggests that the sediments bearing this caudal tube could be correlated to the Urundel Formation (Late Pleistocene) (see below); (b) in the species of the genera Propanochthus and Panochtus there is a clear relationship between the ornamentation pattern of the dorsal surface of the caudal tube and the dorsal carapace: prominent reticular pattern in the dorsal carapace and the same reticular pattern at level of the dorsal surface of the caudal tube (P. tuberculatus, P. subintermedius); in turn, Pr. bullifer and P. intermedius show a prominent development of central figures at the level of the dorsal carapace and the dorsal surface of the caudal tube; finally, this new species shows an intermediate degree of development of central figures in the dorsal carapace, which agrees with the intermediate development of central figures in the caudal tube; 
(a)

(b)

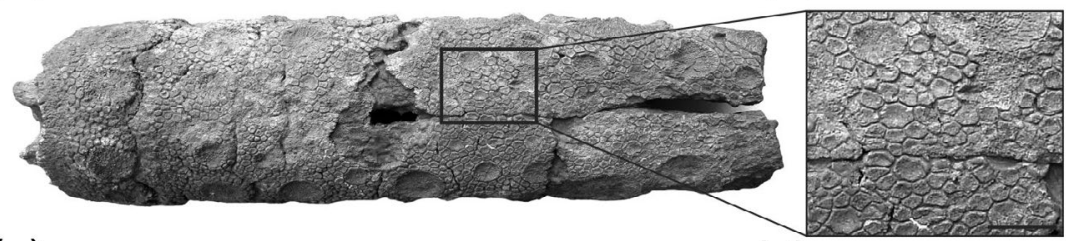

(c)

(d)

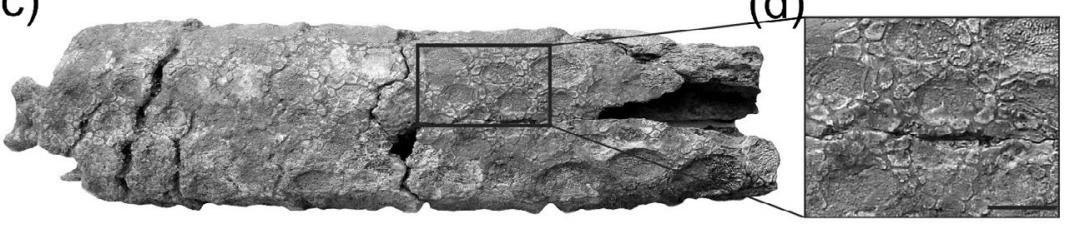

(e)

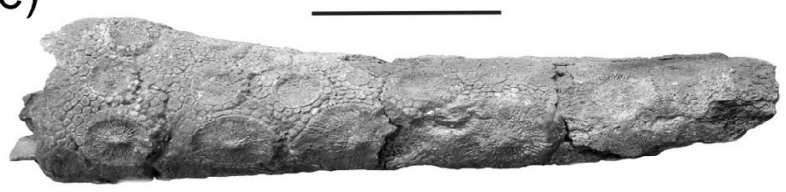

Figure 2. Panochthus hipsilis. MHNS 8. (A), (C), and (E). Caudal tube in dorsal, ventral and lateral views. Scale bar is $150 \mathrm{~mm}$. (B) and (D) detail of the dorsal and ventral surfaces. Scale bar is $20 \mathrm{~mm}$.

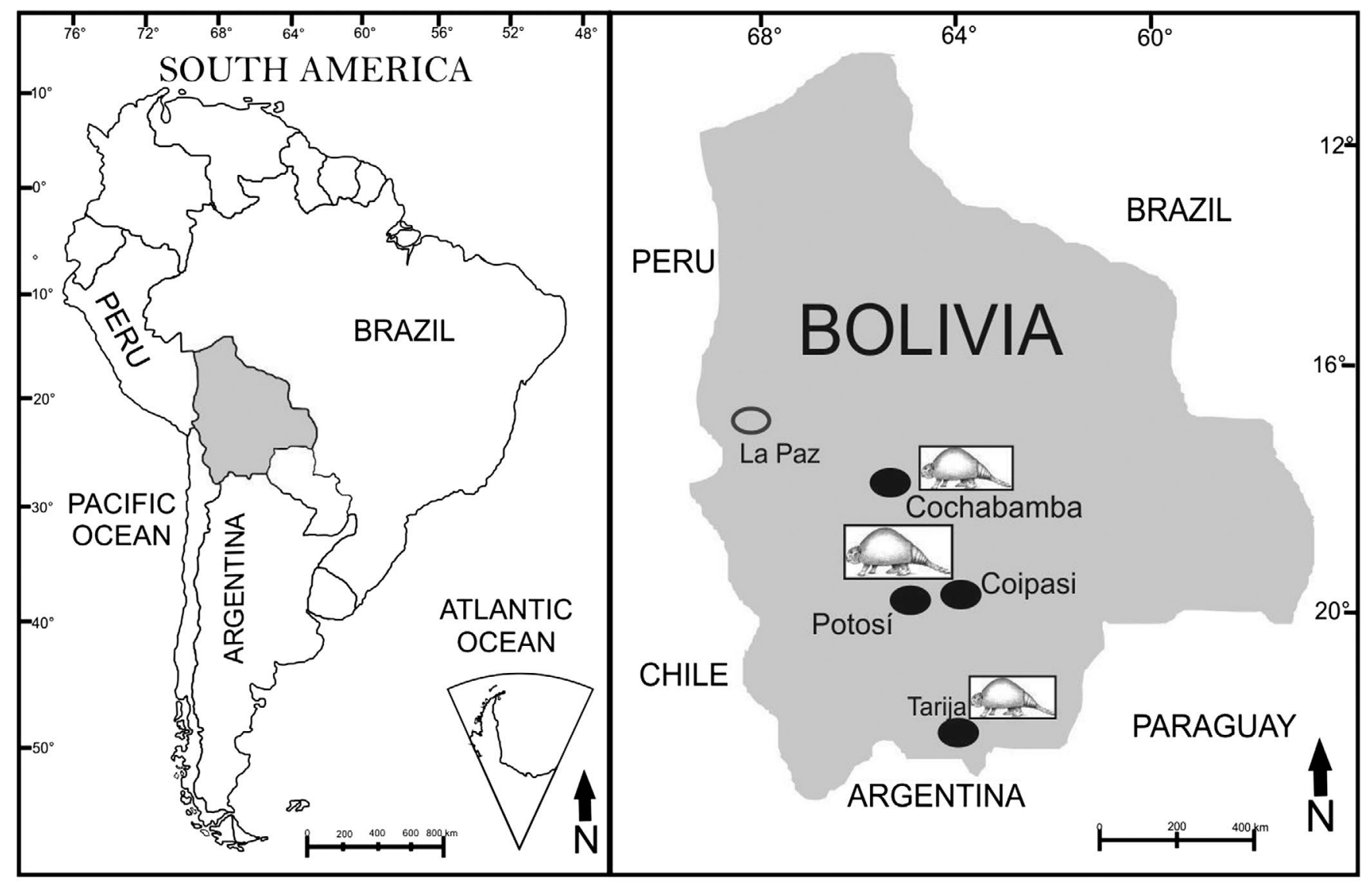

Figure 3. Location map showing localities whit records of Panochthus in Bolivia.

(c) the TL of the dorsal carapace of the type specimen of this new species is $c a .73 \%$ of the length of the dorsal carapaces in $P$. tuberculatus and $P$. frenzelianus, and $c a .66 \%$ of the length of $P$. intermedius. In concordance with these percentages, the caudal tube is ca. $71 \%$ the length of the caudal tube of P. tuberculatus,
P. subintermedius, and P. jaguarifensis and $80 \%$ the length of the caudal tube of Pr. bullifer (Table 1).

Geologic context and stratigraphic origin: most of the Xenarthra Glyptodontidae found in the Andean region of South America are from the eastern Cordillera of Bolivia and 
neighbouring areas. That mountain chain was formed during Neogene by isostasy and a strong thickening of the earth crust. The subsequent regional erosion generated a series of planation surfaces during arid and semiarid periods (Argollo \& Iriondo 2008; Rabassa \& Ollier 2014). The eastern Cordillera was elevated in two main phases; the first phase occurred during the Middle Miocene, about $14 \mathrm{Ma}$; the second began at $8 \mathrm{Ma}$ and continued through the Late Miocene, the entire Pliocene and Early Pleistocene. Both orogenies were followed by an interval of stability, during the late Miocene and a relatively stable Middle and Late Pleistocene and Holocene, respectively. The Quaternary of this cordillera is represented by a sequence of four glaciations, which formed typical U-shaped valleys with glacial till belts in the high valleys and periglacial gravels downstream. The Potosí District (where this new species of Panochthus was found), located at more than 4000 masl, forms the headwaters of the eastern flank of the eastern Cordillera. It is composed of tectonic blocks with a relatively low relief locally, owing to episodes of peneplanation that probably occurred during Early and Middle Pleistocene; the resulting landscape is a plateau morphology with numerous swamps. The original surface was partially filled by coarse alluvial deposits and loess. The loess forms lenses up to $2 \mathrm{~m}$ thick and a few meters long in the outcropping profiles; it was transported in some places. An important outcrop of upper Pleistocene sediments is located in the town Santa Ana ( $40 \mathrm{~km}$ south of Potosí), where the profile is 100 meters thick, composed of loess and transported loess intercalated with coarse gravels. Strata have a typical thickness of $50 \mathrm{~cm}$. Three important planation surfaces are located in the Potosí district. Each of them shapes at present a peneplain with depressions partially filled with loess and swamp muds. The valley landscape downstream includes 10 to $20 \mathrm{~m}$ thick slope deposits. The general structure of the landscape is characterised by 50 to $100 \mathrm{~m}$ hills, carved in Palaeozoic rocks and lower Quaternary sediments. Numerous mass-movement phenomena close the valleys, forming shallow lakes. This scenario suggests the following environmental sequence: Tertiary planation -Early Pleistocene sedimentation - Middle Pleistocene erosion -Late Pleistocene loess sedimentation and gravel transport-Holocene mass-movement phenomena. Although we cannot precisely date the geological unit, the type specimen was recovered from loessic sediments of Late Pleistocene age, which correlate with the Urundel Formation of Argentina, deposited during the Last Glacial Maximum and dated between 17 and $28 \mathrm{ka}$ BP in northwest Argentina (see Iriondo 1990, 2010). Since its finding the type material is located at the Museo Universitario 'Ricardo Bohorquez' (Potosí). In turn, the caudal tube comes from the locality of Coipasi ( $c a .19^{\circ} 60^{\prime} \mathrm{S}-65^{\circ} 43^{\prime} \mathrm{W}$ ), approximately $30 \mathrm{~km}$ east of Potosi and is currently housed in the Museo de Historia Natural de Sucre. As remarked, field observations in both localities (Potosi and Coipasi) suggest these sediments can be correlated to the Urundel Formation. This geological unit covers discontinuously valley bottoms and mountain slopes in the Potosi region, intercalated with coarse alluvial deposits (see Iriondo 1990, 2010). In agreement with this the associated palaeofauna (e.g. Glyptodon and Equus) indicates a Pleistocene age for these sediments.

Diagnosis: Panochthus hipsilis is the smallest species within Panochthus. In P. hipsilis the total length (TL) of the dorsal carapace is $c a .73 \%$ of the length of the dorsal carapaces in $P$. tuberculatus and $P$. frenzelianus, and ca. $66 \%$ of the length of $P$. intermedius. The ratio between the TL of the skull and the TL of the dorsal carapace is 0.31 in P. hipsilis, being this ratio smaller in P. tuberculatus (ca. 0.23) and in P. intermedius (ca. 0.22 ). In turn, the ratio between the TL and the APLDC at level of the dorsal carapace is ca. 0.86 in P. hipsilis, which is different compared to P. tuberculatus (ca. 0.97) and P. intermedius (ca. 0.93 ). Dorsal carapace with an elongated S-shape in lateral profile, as in P. tuberculatus and P. subintermedius, and different from $P$. intermedius and P. fernzelianus. The most lateroventral region with at least four anteroposterior rows of osteoderms having a central figure, which is different from that observed in $P$. intermedius in which there are up to nine rows and a larger number of peripheral figures. At skull level, frontals and nasals are not so ventrally inclined, in contrast to that observed in P. tuberculatus, P. intermedius, P. frenzelianus, and P. cf. P. subintermedius. Rostral area more anteroposteriorly elongated compared to the remaining species, except $P$. intermedius. Rostral area clearly laterally expanded as in $P$. intermedius. Orbitals posteriorly closed by a postorbital bar, as in $P$. tuberculatus, in contrast to $P$. frenzelianus, $P$. intermedius, and $P$. cf. P. subintermedius, in which the orbitals are posteriorly open. Caudal tube shorter compared to those of the remaining species of Panochthus and Pr. bullifer. Dorsal surface showing a rosette ornamentation pattern, which is different from those of $P$. tuberculatus, $P$. subitermedius, $P$. jaguaribensis and P. greslebini in which the caudal tube shows a more reticular pattern.

\section{Comparative description}

Skull (Figure 1(a)-(d): The skull is nearly complete, except for both zygomatic arches and most of the frontal and parietal areas, which are not preserved. It is similar in size to that of $P$. tuberculatus and $P$. frenzelianus, but much smaller compared to Panochthus cf. P. subintermedius (see Zamorano et al. 2013) (Table 1). In frontal view (Figure 1(a)), the rostral area shows the same general morphology of Panochthus, but it is more laterally expanded than in $P$. tuberculatus, and $P$. frenzelianus, as in $P$. intermedius. In addition, the upper notch of the nasal openings is more developed than in the other species, showing a notable similarity with $P$. intermedius. As mentioned above, the anterior edge of the orbital notch develops a prominent bony ridge, similar in morphology to that of $P$. intermedius whereas in the remaining species this structure is not present or is much less developed. In overall morphology, the nasal openings show a notable resemblance to $P$. intermedius.

In lateral view (Figure 1(b) and (c)), the rostral area located anterior to the orbital notches has the typical morphology of Panochthus, but possesses some remarkable differences compared to the rostral areas of those species in which skull is known (P. tuberculatus, $P$. intermedius, $P$. cf. P. subintermedius, and $P$. frenzelianus). In the new species, the frontals and nasals are ventrally inclined, as usual in Panochthus, but this is not as pronounced as in the remaining species. The angle between the palatal plane and the dorsal surface of the rostral area is ca. $65^{\circ}$, whereas this angle reaches ca. $50^{\circ}$ in P. frenzelianus, $P$. tuberculatus, and ca. $60^{\circ}$ in P. intermedius (see Zurita, Zamorano, et al. 2011; Zamorano 2012). Another significant difference involves the anteroposterior length of the rostral area, which is 
much more prominent than in the other species, most closely resembling that of $P$. intermedius. In $P$. hipsilis the anteroposterior diameter of this area represents $c a .50 \%$ of the anteroposterior length of the orbital notch, whereas in P. tuberculatus and P. frenzelianus this proportion is $c a .65 \%$. Curiously, the right lateral surface shows a small mark that resembles a bite. The nasal openings show the typical morphology of the other species of Panochthus. The orbital notch is subcircular, resembling that of $P$. tuberculatus, and P. intermedius. As in this latter species, the posterior edge is posteriorly inclined whereas the anterior and dorsal edges possess a bony ridge. The ventral-most extremity of the descending process of the maxilla is not preserved, but the general morphology is very similar to that of $P$. tuberculatus and $P$. frenzelianus. In contrast, in P. intermedius this structure presents a more developed anterior-posterior diameter, especially in its dorsal part. Regrettably, only the most anterior part of the right zygomatic arch is preserved, precluding any comparison.

In dorsal view (Figure $1(\mathrm{~d})$ ), the only well-preserved region is located anterior to the orbitals. Its morphology is similar to that of the other species, showing a triangular outline, although not so pronounced as in P. tuberculatus and P. frenzelianus. In these species the lateral margins are straight, delimiting an almost perfect triangle. In P. hipsilis these margins are not completely straight, showing some resemblance with $P$. intermedius. The orbitals are posteriorly closed by a postorbital bar, as in P. tuberculatus, and different from those of $P$. frenzelianus, $P$. intermedius, and P. cf. $P$. subintermedius, in which the orbitals are posteriorly opened. As mentioned above, the dorsal edge of the orbital notch presents a bony ridge similar in morphology to that of $P$. intermedius.

In occipital view, there are no significant differences with respect to the other species of the genus.

Dorsal carapace (Figure 1(e)): The dorsal carapace is almost complete, but lacks the most ventral part of the lateral region of both sides; however, several fragments of associated osteoderms of this region are preserved allowing comparisons with homologous areas. The total length (TL) of the dorsal carapace is ca. $73 \%$ of the length of the dorsal carapaces in P. tuberculatus and $P$. frenzelianus, and $c a .66 \%$ of the length of $P$. intermedius. The dorsal profile is similar to that of P. tuberculatus and P. subintermedius, which is an elongated S-shape in lateral view, and unlike that of $P$. intermedius and $P$. frenzelianus in which the dorsal profile is more convex (see Cruz et al. 2011). As in all the species of Panochthus, the ornamentation of the osteoderms of central-dorsal region is a clear 'reticular' pattern, composed of small polygonal figures of similar size. Although the holotype of Pr. bullifer does not preserve the dorsal region of the dorsal carapace, it seems that Burmeister (1874, p. 151) observed more remains of this specimen when he stated that this region shows a reticular pattern. Supporting the observations of Burmeister, it is possible to identify in the preserved dorsal carapace of Pr. bullifer at least two osteoderms showing a complete reticular pattern. This pattern is different from that of Nopachtus coagmentatus and N. cabrerai, in which the dorsal carapace shows a distinctive 'rosette' pattern consisting of a central figure generally surrounded by two rows of small peripheral figures. The dorsal-anterior region of the carapace of $P$. hipsilis (Figure 1(f)) shows a complete reticular pattern, as in $P$. subintermedius, $P$. tuberculatus, $P$. frenzelianus. In contrast, in $P$. intermedius there is an evident 'rosette' pattern: in this area, each central figure is surrounded by three to four rows of small, peripheral, polygonal figures. These central figures become smaller toward the distal region. On the other hand, N. cabrerai and N. coagmentatus present fewer rows (up to two) of peripheral figures.

The posterodorsal region of the carapace of $P$. hipsilis (Figure $1(\mathrm{~g})$ ) shows a reticular pattern, except the penultimate row, where each osteoderm has a flat and somewhat rough subcircular central figure surrounded by two or three rows of polygonal, peripheral figures. According to Ameghino (1889, p. 302), this character is also present in P. tuberculatus (e.g. MLP 16-29; see Zamorano 2012), but it is probable that this represents an intraspecific variation because some specimens assignable to this species show a reticular pattern along the entire dorsal carapace (e.g. MPAC s $/ \mathrm{n}^{\circ}$ ). A very similar condition of $P$. hipsilis is observed in the material figured by Porpino et al. (2014, Figure 5G) and classified as Panochthus sp. from the Pleistocene of north-eastern Brazil. In contrast, in P. frenzelianus and $P$. subintermedius this area bears a complete 'reticular' pattern. In P. intermedius it is possible to observe several rows of osteoderms (up to six) bearing a slightly convex central figure that presents a rougher surface compared to P. hipsilis, showing some similarity with Pr. bullifer. As in the anterior region, the central figures become smaller toward the middle area, also as observed in Pr. bullifer. In P. hipsilis, each central figure presents, in general, a lower number of rows surrounding each central figure and the peripheral figures are larger compared to those of $P$. intermedius. In most of the preserved dorsal carapace (posterior-dorsal region) of Propanochthus bullifer, it is possible to differentiate in each osteoderm a large central figure, generally elevated, surrounded by up to five rows of peripheral figures. This region is morphologically similar to that seen in P. intermedius. In Nopachtus cabrerai the rosette ornamentation pattern differs by having a convex central figure surrounded by a small number (up to 12) of peripheral figures and one or two rows of peripheral figures.

In $P$. hipsilis the osteoderms of the caudal notch are very similar to those of Pr. bullifer, P. tuberculatus and P. intermedius. There is a central figure posteriorly displaced and anteriorly surrounded by several (3-5) rows of small peripheral figures.

The lateral area of the dorsal carapace of $P$. hipsilis (Figure $1(\mathrm{~h})$ ) is very similar in its general morphology to that of the other species of Panochthus, in which the anterior and posterior areas show mobile bands of osteoderms, and thus similar to the Glyptodontidae Propalaehoplophorinae (Propalaehoplophorus Ameghino and Eucinepeltus Ameghino). The most lateroventral osteoderms present a clearly distinguishable central figure surrounded by small polygonal figures, as in $P$. intermedius, $P$. frenzelianus, and P. tuberculatus (see Burmeister 1874). In this sense, Porpino et al. (2014, figure 5, D-F) figured two osteoderms classified as Panochthus sp. that show a very similar morphology. As observed in P. intermedius, these central figures become smaller toward the dorsal region, where they completely disappear. The fact that these lateral portions of carapace were not associated with the dorsal carapace precludes inferring how many rows of osteoderms bear this ornamentation; however, our observations indicate that at least four rows of osteoderms have this morphology. This is different from $P$. intermedius, in which the lateral region have a larger number of antero-posterior rows of osteoderms having a central figure (up to 9 in some regions) and, in general, a large number of peripheral figures as well. In $P$. intermedius and $P$. hipsilis, the 
anterior margin of the central figure is surrounded by two rows of peripheral figures, whereas the lateral and posterior margins are surrounded by one row. Burmeister (1874) and Cruz et al. (2011) mentioned the presence of an antero-posterior row of osteoderms bearing a central figure in P. tuberculatus, but this character seems to be variable because at least one specimen assignable to this species shows a complete reticular pattern (e.g. MPAC $s / n^{\circ}$ ). With regard to Pr. bullifer, Burmeister (1874, p. 151) remarked that it possesses at last eight antero-posterior rows of osteoderms having a central figure in the lateral region of the dorsal carapace. As previously mentioned, it seems very probable that Burmeister observed in the field more remains belonging to the holotype than those currently preserved (see Zamorano 2013).

Caudal tube (Figure 2(a)-(e): The caudal tube is almost complete, only missing the most distal portion. It is $640 \mathrm{~mm}$ long, being much shorter compared to the remaining species of Panochthus. In fact, the caudal tubes of $P$. tuberculatus, $P$. subintermedius and P. jaguaribensis are between 29\% and 34\% longer than that of $P$. hipsilis, whereas the caudal tube of Pr. bullifer is $c a$. $20 \%$ longer. The dorsal surface of the caudal tube bears subcircular central figures (Figure 2 (a)). Each central figure presents a flat and smooth surface and is surrounded by eight to eleven peripheral figures (Figure 2 (b)), showing some resemblance with Pr. bullifer. However, this particular morphology is different from Panochthus tuberculatus, P.greslebini, P. subitermedius and $P$. jaguaribensis, in which this dorsal surface shows a more evident reticular pattern (similar to that observed in the dorsal area of the dorsal carapace), although some central figures can be observed. In turn, P. intermedius is, together with Pr. bullifer, the other species having well-developed central figures in the caudal tube, but in this taxon these are clearly extended anteroposteriorly and depressed, with a very rugose surface, showing a very different morphology compared to $P$. hipsilis. The ventral surface bears subcircular central figures (Figure 2(c)), like in the dorsal surface, but the central figures are more anteroposteriorly extended (Figure 2(d)), presenting some similarity with $P$. intermedius. As in all species of Panochthus and in Pr. bullifer, the laterals of the caudal tube have large laterals figures with a very rugose surface (Figure 2(e)).

\section{Phylogenetic affinities of P. hipsilis within Panochthus and allied genera}

In order to test the location of P. hipsilis within Panochthus and allied genera, we performed a cladistic analysis. The matrix included 16 taxa and 37 morphological characters (Appendix 3). Most characters are based on some previous analyses (Zamorano \& Brandoni 2013; characters 2-14, 16-20; 22, 24-33), and Zurita (2007; character 1534) whereas 7 are new characters $(1,21,23$, $29,35,36,37)$ were added. The characters included 18 from the skull and dentition, 11 from the dorsal carapace, and 8 from the caudal armor (Appendix 2). Twenty-four are binary characters and 13 are multistate (treated as non-additive). All characters were treated as unordered, with the same weight (1.0). Characters states that were not preserved were coded as '?? The matrix was developed through the Nexus Data Editor (0.5.0) software. The character-taxon matrix (Appendix 3) was analysed via 'Implicit enumeration' using 'TNT', under the criterion of maximum parsimony (Goloboff et al. 2008). Clade support was accessed via Relative Bremer support (from 1363 trees; see Bremer 1994; Goloboff \& Farris 2001); in addition to the bootstrap analysis we used the option 'Implicit enumeration', with 1000 replicates. All the characters were scored via direct observation of the specimens. The in-group include the following taxa: $P$. tuberculatus, $P$. intermedius, $P$. subintermedius (including $P$. cf. subintermedium; see Zamorano et al. 2013), P. hipsilis and P. greslebini. P. frenzelianus was excluded from this analysis due to some problems concerning the identification of the type material (see Cruz et al. 2013). P. jaguaribensis was also excluded because the only known materials of this species are limited to two caudal tubes (see Porpino et al. 2014). The Miocene Glyptodontidae Propalaehoplophorinae Propalaehoplophorus australis (see González Ruiz 2010) was used to root the tree. In addition to this, the out-group is composed of Glyptodon reticulatus, Hoplophorus euphractus, Pseudoplohophorus absolutus, Plohophorus figuratus, Nopachtus cabrerai, N. coagmentatus, Phlyctaenopyga ameghini, Stromaphorus compressidens and Neosclerocalyptus ornatus.

The cladistic analysis resulted in 1 MPT (LT: 75 RI: 0.790; CI: 0.667) (Figure 4). In the observed topology, the Glyptodontinae G. reticulatus appears as the sister taxa of the remaining Glyptodontidae, as seen in Zurita et al. (2013). The remaining Glyptodontidae are included in two large clades. In node A Neosclerocalyptus ornatus appears as the sister taxa of two well defined clades. One is formed by the 'Plohophorini' (Plohophorus figuratus + Pseudoplohophorus absolutus), whereas the other is formed by a polytomy among Nopachtus cabrerai, $N$. coagmentatus and the clade constituted by Phlyctaenopyga ameghin + Stromaphorus compressidens. As observed by Porpino et al. (2014) the condition of natural group of the genus Nopachtus remains problematic. Evidently, this problem is largely due to the poor characterization of both species. In the other large clade (node B), the intertropical species Hoplophorus euphractus is located as the sister taxa of the clade including Propanochthus bullifer + (Panochthus spp.). This clade is supported by the presence of lateral figures of the caudal tube modified in 'spines' (36:1). Interestingly, this character is optimized in N. coagmentaus as a homoplasy (see Porpino et al. 2014). In turn, node C includes Pr. bullifer and the species of the genus Panochthus, where Pr. bullifer is located as the sister taxa of Panochthus spp. Three synapomorphies support this condition: each central figure of the osteoderms of the posterior region of the dorsal carapace is surrounded by 4-7 rows of small peripheral figures (25:0); these small peripheral figures occupy more than the 50\% of the exposed surface of the osteoderms (28:1); the central figure of the most proximal row of the caudal tube is clearly rugose (35:1). This result is different from that observed in the analysis of Porpino et al. (2014), where Pr. bullifer appears as closely related to N. cabrerai, whereas in Zamorano and Brandoni (2013) Pr. bullifer is located within a polytomy with Nopachtus spp., S. compressidens and P. ameghini. The topology observed in this contribution is interesting because Pr. bullifer was originally recognized by Burmeister (1874) as belonging to the genus Panochthus. Moreover, the comparative morphology of the caudal tube of Panochthus and Pr. bullifer reveals some shared characters. This is especially evident in the morphology of the most proximal part of the caudal tube and in the lateral figures. In turn, the genus Panochthus (node D) constitutes a natural group and its topology 


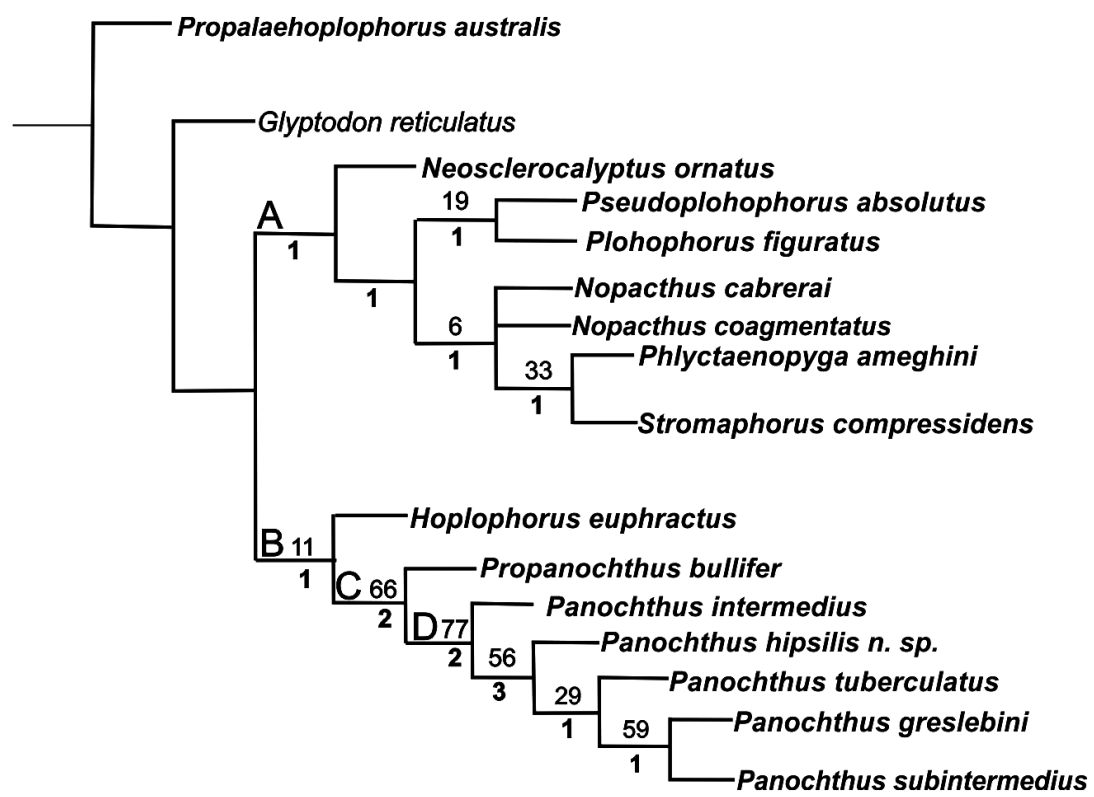

Figure 4. Phylogeny of Glyptodontinae based on TNT analysis of 37 osteological characters in 17 taxa (LT: 75; Cl: 0.667; RI: 0.790). Note: The numbers above each node represent bootstrap values; numbers in bold show Relative Bremer support.

is similar to that obtained by Porpino et al. (2014). This condition is supported by the presence of a complete reticular pattern in the dorsal region of the dorsal carapace (21:1) and rough central figures in the dorsal region of the caudal tube (32:2). Within Panochthus, P. intermedius (early-middle Pleistocene) occupies the most basal position, being the sister taxa of the remaining species. This clade is supported by four synapomorphies: the highest point of the dorsal carapace is located in the anterior region (20:1); the absence of central figures in the anterior (22:1) and caudal (26:2) regions of the carapace that show a complete reticular pattern (25:2). Interestingly, $P$. hipsilis occupies a more basal position than Panochthus tuberculatus (late Pleistocene), which in turn is placed as the sister taxa of the most derived taxa ( $P$. greslebini and $P$. subintermedius). The clade composed of $P$. tuberculatus and the remaining species (P. greslebini $+P$. subintermedius) includes two synapomorphies: the presence of a reticular pattern in the osteoderms of the posterior region of the dorsal carapace (23:2) and absence of central figures in this region of the dorsal carapace (27:2). Finally, the clade containing $P$. greslebini and $P$. subintermedius is characterized by a pointed morphology of the distal end of the caudal tube (33:1).

As observed by Porpino et al. (2014) the obtained topology contradicts in part the phylogenetic scheme proposed by Castellanos (1942). According to Castellanos (1942) P. subintermedius (Early-Midle Pleistocene) occupied an intermediary phyletic position between $P$. intermedius and the Middle to Late Pleistocene species of the genus. However, P. subintermedius constituted with $P$. greslebini the most derived node in the obtained topology.

\section{Results and discussion}

Castellanos (1927) was the first to group the genera Nopachtus, Propanochthus and Panochthus into the subfamily Panochthinae (Pliocene-Pleistocene), some years later transferred by Simpson
(1945) to the category of a tribe (Panochthini). In a pre-cladistic scenario, Castellanos (1942, p. 419) postulated a single evolutionary lineage characterized by a progressive 'change' from a 'rosette' ornamentation pattern (i.e. a central figure surrounded by one or more rows of peripheral figure) to a 'reticular' pattern occupying most of the exposed surface of the dorsal carapace, as observable in some specimens of the terminal species $P$. tuberculatus and P. frenzelianus. According to Castellanos (1942, p. 418), the lineage containing Nopachtus (the most primitive integrant of this sequence followed by Propanochthus and Panochthus) and Stromaphorus ('Plohophorini') had its origin in the Patagonian early-middle Miocene Propalaehoplophorus. More recently, the Panochthini were postulated as phylogenetically close to the 'Plohophorini' because of the multiplication of the peripheral figures in the osteoderms of the dorsal carapace in both taxa (Hoffstetter 1958; Carlini \& Scillato-Yané 1999).

Although the cladistic analyses carried out in Glyptodontidae are still scarce compared to other clades of Xenarthra (i.e. Tardigrada and Cingulata Dasypodidae) the new evidence strongly suggests that many of the traditionally recognized groups in glyptodonts are in fact non-natural groups (see Fernicola 2008; Porpino et al. 2010). This problematic situation includes also the 'Panochthini' which, according to Zamorano (2013) and Zamorano and Brandoni (2013) does not constitute a natural group, because Nopachtus and Propanochthus appear as phylogenetically more related to some 'Plohophorini' than to Panochtus (see also Porpino et al. 2014). These results imply that the multiplication of peripheral figures could have originated more than once in Glyptodontidae.

In agreement with the previous cladistic analyses, the results obtained herein show that the 'Panochthini' does not constitute a natural group, whereas the genus Panochthus is a clearly recognizable clade. However, and in contrast to that observed in previous analyses (see Zamorano \& Brandoni 2013; Porpino et al. 2014) Pr. bullifer is placed as the sister taxon of Panochthus. 
This is an interesting result because Pr. bullifer was originally included in the genus Panochthus by Burmeister (1874) and later transferred by Castellanos (1925) to Propanochthus, but denoting its very close relationship with Panochthus.

Reinforcing the close phylogenetic affinities observed between Panochthus and Propanochthus, the comparative study supports this interpretation. At the level of the dorsal carapace, one of the most distinctive characters in Panochthus is represented by the presence of a reticular pattern in the dorsal region of the dorsal carapace (Hoffstetter 1958). Interestingly, although the type material of Pr. bullifer does not preserve this area, Burmeister (1874, p. 151; see also Castellanos 1942) remarked that the dorsal region of the dorsal carapace shows a reticular pattern. This interpretation is concordant with our observations because some of the most proximal osteoderms show an almost complete reticular pattern. Also, an interesting similarity between Pr. bullifer and $P$. intermedius is observable at the level of the osteoderms forming the caudal notch and the postero-dorsal region not observed in Nopachtus (see Descriptions). The caudal tube of Pr. bullifer also shows a very close morphology when compared to Panochthus. This is especially evident in the central figures of the second row of osteoderms at the level of first associated caudal ring, and in the lateral figures, which are almost identical to those of Panochthus, as claimed by Burmeister (1874, p. 152-153). This set of characters is shared only by Panochthus and Propanochthus.

With regard to geographic latitude and elevation, there are some interesting points to consider, especially concerning the distribution of the Pleistocene species of Panochthus which, together with Glyptodon Owen, represent the most widespread glyptodonts in South America (Zurita et al. 2009). In this continent, from $20^{\circ} \mathrm{S}$ northward it is possible to observe a change in the Pleistocene diversity of glyptodonts present in the Pampean region of Argentina, Uruguay and southern Brazil that includes at least five genera (i.e. Neosclerocalyptus, Neuryurus, Doedicurus, Glyptodon and Panochthus). From $20^{\circ} \mathrm{S}$ northward to $10^{\circ} \mathrm{N}$, the glyptodonts are represented almost exclusively by the Glyptodontinae Glyptodon and cf. Glyptotherium, Panochthus and some isolated records of Hoplophorus (Zurita et al. 2009; Carlini \& Zurita 2010; Porpino et al. 2010, 2014). However, some remarkable differences are observable when compared the western and eastern areas of South America. In the western region and parallel to the Andes Mountains the diversity of glyptodonts includes a predominance of Glyptodon (reaching elevations up to $3300 \mathrm{~m}$ ), followed by some records of Panochthus (Carlini \& Zurita 2010; Zurita et al. 2012). In fact, this report constitutes one of the highest known elevation records for fossil Xenarthra $(\sim 4000 \mathrm{~m})$, taking into account that the Pleistocene elevation of this area was similar to the current elevation (see Benjamin et al. 1987). The eastern region shows a different pattern, where the genera Glyptodon and Panochthus are dominant, including some records of Hoplophorus and cf. Glyptotherium in Brazil and Venezuela (Carlini, Zurita, Scillato-Yané et al. 2008; Oliveira et al. 2010; Porpino et al. 2010, 2014). Even if at generic level both regions (western and eastern) share the same genera (except Glyptotherium), the species are different. In the Brazilian Intertropical Region (sensu Cartelle 1999) two endemic species of Panochthus (P. greslebini and P. jaguaribensis) have been postulated (Porpino et al. 2014; but see Zamorano et al. 2015), whereas the taxonomic identification of the records of Glyptodon remains problematic because they are limited to isolated and/or associated osteoderms (see Zurita, Oliveira, et al. 2011).

On the other hand, the western diversity of Pleistocene glyptodonts is currently under study, but preliminary observations strongly indicate that the records of Glyptodon constitute a new species (unpublished), in addition to $P$. hipsilis (Zurita et al. 2016). This a very interesting point, because the linear measurements of $P$. hipsilis of the skull are very similar to those of the Pampean species $P$. tuberculatus, but the dorsal carapace and caudal tube are smaller. When comparing to the Early Pleistocene species $P$. intermedius at dorsal carapace level the difference is even more evident (see Table 1). In addition, the morphology of the skull and the caudal tube present a particular morphology, very different from that of the remaining species of Panochthus. In this sense, our preliminary observations about the specimens of Glyptodon show a very similar pattern. The total length of the dorsal carapace of one specimen (MP 3) coming from the locality of Puna (Potosi) (3300 m.a.s.l.) is approximately $70 \%$ of the length of the dorsal carapace in G. reticulatus (MCA 2015), and the general morphology of the dorsal carapace is very different compared to that of the Pampean species G. reticulatus and G. munizi. Among Xenarthra, this trend is also particularly evident in Quaternary Megatheriinae, in which it is possible to observe the existence of a well-defined subclade of Andean species, grouped in the subgenus Megatherium Cuvier (Pseudomegatherium) Kraglievich (see PUJOS 2006).

\section{Conclusion}

As pointed out by previous authors (Zamorano 2012; Zamorano \& Brandoni 2013; Porpino et al. 2014), the phylogenetic analysis indicates that Panochthus constitutes a natural group, whereas the monophyly of 'Panochthini' is rejected, because Nopachtus and Phlyctaenopyga appear as closely related to some species of 'Plohophorini'. Another interesting result, not observed in previous phylogenetic analyses, is represented by the location of Pr. bullifer as the sister taxon of Panochthus. This is, at least in part, in agreement with the original proposal of Burmeister (1870-1874) who originally included this species in Panochthus. From a phylogenetic viewpoint, Panochthus hipsilis occupies a relatively basal position among Panochthus, being the sister taxon of the remaining species of Panochthus except $P$. intermedius. From a morphologic view point, $P$. hipsilis shows some remarkable characters, such as the presence of well-developed central figures in the dorsal surface of the caudal tube, at least four antero-posterior rows of lateral osteoderms bearing central figures.

Panochthus and Glyptodon are the genera that show the widest latitudinal distribution and range of elevation, which in turn can explain this notable diversification among the Pleistocene Glyptodontidae in South America. The evidence now suggests that the Pleistocene diversity of Glyptodontidae from Andean and sub-Andean regions of South America is limited to the genera Panochthus and Glyptodon, which present a very particular morphology. Their dorsal carapaces and caudal armors are significantly smaller compared to those of the lowland species of both genera. 


\section{Acknowledgments}

We are grateful to the different institutions for allowing the study of material under their care. The Willy Hennig Society allowed free access to TNT software. Both reviewers (D. Croft and E. Soibelzon) are also thanked for their thorough reviews and helpful suggestions.

\section{Disclosure statement}

No potential conflict of interest was reported by the authors.

\section{Funding}

This work was funded by CONICET [project PIP 0150]; SGCyT-UNNE [project PI Q001/13]; the Colbert Endowment and research fund donations to the Geology Department at the Museum of Northern Arizona.

\section{References}

Abba AM, Tognelli MF, Seitz VP, Bender BJ, Vizcaíno SF. 2012. Distribution of extant xenarthrans (Mammalia: Xenarthra) in Argentina using species distribution models. Mammalia. 76:123-136.

Ameghino F. 1889. Contribución al conocimiento de los mamíferos fósiles de la República Argentina [Contribution to the knowledge of the fossil mammals from Argentine]. Actas Acad Nac Ciencias Córdoba. 6:11028.

Argollo J, Iriondo M. 2008. El Cuaternario de Bolivia y regiones vecinas [The Quaternary of Bolivia and neighboring regions]. Mus Prov Cienc Nat "Florentino Ameghino". 1-378.

Báez-Presser JL, Buongermini E, Amábile VOF, Crossa VF, Báez-Almada AB, Zarza-Lima PR, Migone OO. 2004. Algunos antecedentes paleontológicos del Paraguay [Some paleontological background from Paraguay]. Bol Mus Hist Nat Paraguay. 15:95-110.

Benjamin MT, Johnson NM, Naeser CW. 1987. Recent rapid uplift in the Bolivian Andes: evidence from fission-track dating. Geology. 15:680683.

Bremer K. 1994. Branch support and tree stability. Cladistics. 10:295-304.

Burmeister G. 1866. Lista de los mamíferos fósiles del terreno diluviano. An Mus Pub Buenos Aires. 1:121-232.

Burmeister G. 1874. Monografía de los Glyptodontes en el Museo Público de Buenos Aires [Monograph of the Glyptodonts in the Public Museumof Buenos Aires]. An Mus Pub Buenos Aires. 2:1-412.

Carlini AA, Vizcaíno SF, Scillato-Yané GJ. 1997. Armored Xenarthrans: a unique taxonomic and ecologic assemblage. In: Kay RF, Madden RH, Cifelli RL, Flynn JJ, editors. Vertebarte Paleontology in the Neotropics, Volume 13. Colombia; Washington: The Miocene Fauna of La Venta; Smithsonian Institution Press; p. 213-232.

Carlini AA, Scillato-Yané GJ. 1999. E Quaternary of South America and Antarctic Peninsula. In: J Rabassa, M Salemme. Evolution of Quaternary Xenarthrans (Mammalia) of Argentina, Chapter 12. Volume 10. Amsterdam; p. 149-176.

Carlini AA, Zurita AE, Aguilera O. 2008. North American glyptodontines (Xenarthra, Mammalia) in the upper Pleistocene of northern South America. Palaeontol Z. 82:139-152.

Carlini AA, Zurita AE, Scillato-Yané GJ, Sánchez R, Aguilera O. 2008. New Glyptodont from the Codore Formation (Pliocene), Estado Falcón (Venezuela), its relationship with the 'Asterostemma' problem, and the paleobiogeography of the Glyptodontinae. Palaeontol Z. 82:125-138.

Carlini AA, Zurita AE. 2010. Urumaco and Venezuelan paleontology. In: M Sánchez-Villagra, O Aguilera, AA Carlini. An introduction to Cingulate Evolution and their evolutionary history during the Great American Biotic Interchange: biogeographical clues from Venezuela, Chapter 12; Bloomington, Indiana: Indiana University Press. p. 233-255.

Castellanos A. 1925. Breves notas sobre evolución de la coraza y del extremo caudal en losLoricata (Hicanodonta) [Short notes about the evolution of the carapace and the caudal armor in the Loricata]. Revista de "El Circulo", número extraordinario: 93-96.

Cartelle C. 1999. Mammals of the Neotropics. In: JB Eisenberg, KH Redford. Pleistocene mammals of the Cerrado and Caatinga of Brazil,
Volume 3; Chicago, IL: The Central Tropics. University of Chicago Press. p. 27-46.

Castellanos A. 1927. Descripción de un fragmento de tubo caudal de undoedicurino en relación con sus géneros afines [Description of a fragment of caudal tube belonging to a Doeducurinae in relationship with its allied genera]. An Mus Hist Nat Montevideo. 2:265-300.

Castellanos A. 1942. A propósito de los géneros Plohophorus, Nopachthus y Panochthus (3a. parte) [About the genera Plohophorus, Nopachthus and Panochthus]. Pub Inst Fisio y Geol. 11:413-592.

Cione AL, Tonni EP. 2005. Biostratigrafía basada en mamíferos del Cenozoico superior de la provincia de Buenos Aires, Argentina [Biostratigraphy based on mammals from the upper Cenozoic of the province of Buenos Aires, Argentina]. In: de Barrio R, Etcheverry M, Capalté M, Llambías E, editors. Geología y Recursos Minerales de la Provincia de Buenos Aires. La Plata: XVI Congreso Geológico Argentino. Relatorio; 11: p. 183-200.

Cozzuol MA. 2006. The Acre vertebrate fauna: age, diversity, and geography. J S Am Earth Sci. 21:85-203.

Croft DA, Flynn JJ, Wyss AR. 2007. A new basal Glyptodontoid and other Xenarthra of the early Miocene Chucal Fauna, Northern Chile. J Vert Paleontol. 27:781-797.

Cruz LE, Zamorano M, Scillato-Yané GJ. 2011. Diagnosis and redescription of Panochthus subintermedius Castellanos (Xenarthra, Glyptodontidae) from the Ensenadan (early-middle Pleistocene) of Buenos Aires. Palaeontol Z. 85:115-123.

Cruz LE, Fernicola JC, Porpino KO. 2013. A propósito del Neotipo de Panochthus tuberculatus (Owen, 1845) (Mammalia, Xenarthra, Glyptodontoidea) [About the neotype of Panochthus tuberculatus (Owen, 1845) (Mammalia, Xenarthra, Glyptodontoidea)]. Rev Bras Pal. 16:331-340.

Cruz LE, Fernicola JC, Taglioretti M, Toledo N. 2016. A reassessment of the taxonomic status of Paraglyptodon Castellanos, 1932 (Mammalia, Cingulata, Glyptodontia). J South Amer Earth Sci. 66:32-40.

Fernicola JC. 2008. Nuevos aportes para la Sistemática de los Glyptodontia Ameghino 1889 (Mammalia, Xenarthra, Cingulata) [New contributions to the systematics of the Glyptodontia]. Ameghiniana. 45:553-575.

Frailey CD. 1988. The Miocene vertebrates of Quebrada Honda, Bolivia. Part II. Edentata. Occasional Papers of the Museum of Nat Hist, Univ Kans. 123:1-13

Gaudin TG, Croft DA. 2015. Paleogene Xenarthra and the evolution of South American mammals. J Mammal. 96:622-634.

Gillette DD, Carranza-Castaneda O, White RS Jr, Morgan GS, Thrasher LC, McCord R, McCullough G. 2016. Ontogeny and sexual dimorphism of Glyptotherium texanum (Xenarthra, Cingulata) from the Pliocene and Pleistocene (Blancan and Irvingtonian NALMA) of Arizona, New Mexico, and Mexico. J Mamm Evol. 23:133-154.

Goloboff PA, Farris JS. 2001. Methods for quick consensus estimation. Cladistics. 17:S26-S34.

Goloboff PA, Farris JS, Nixon KL. 2008. TNT, a free program for phylogenetic analysis. Cladistics. 24:774-786.

González Ruiz LR. 2010. Los Cingulata (Mammalia, Xenarthra) del Mioceno temprano y medio de Patagonia (edades Santacrucense y "Friasense"). Revisión sistemática y consideraciones bioestratigráficas [The Cingulata (Mammalia, Xenarthra) from the Early-Middle Miocene of Patagonia. Systematics revision and biostratigraphic considerations] [Ph. D. thesis]. La Plata, Buenos Aires: Universidad Nacional de La Plata.

González Ruiz LR, Scillato-Yané GJ, Zamorano M, Zurita AE, Tejedor MF. 2011. Un nuevo Glyptodontidae (Mammalia, Xenarthra, Cingulata) del Mioceno de Patagonia (Argentina) y comentarios acerca de los gliptodontes del SALMA "Friasense" [A new Glyptodontidae (Mammalia, Xenarthra, Cingulata) from the Miocene of Patagonia (Argentina) with comments about the glyptodonts from the Friasian SALMA]. Rev Mex Cs Geol. 28:566-579.

González Ruiz LR, Ciancio M, Martín G, Zurita AE. 2015. First record of supernumerary teeth in Glyptodontidae (Mammalia, Xenarthra). J Vert Paleontol. 35:1-6.

Hoffstetter R. 1958. Xenarthra in Traité de Paléontologie. In: J Piveteau. Masson et Compagnie. Paris. 6; p. 535-563.

Hoffsfetter R. 1970. Vertebrados cenozoicos y mamíferos cretácicos del Perú. $4^{\circ}$ Congreso Latinoamericano de Zoología. Caracas: Actas [Cenozoic vertebrates and Cretacic mammals from Peru]. 2:971-983. 
Iriondo MH. 1990. La Formación Urundel, un loess chaqueño [Urundel formation, a loess from Chaco]. International Symposium on loess, Expanded abstracts; p. 89-90.

Iriondo MH. 2010. Geología del Cuaternario en Argentina [Quaternary geology in Argentina]. Corrientes, Argentina: Editorial Moglia; p. 437.

Krmpotic CM, Ciancio MR, Barbeito C, Mario RC, Carlini AA. 2009. Osteoderm morphology in recent and fossil euphractine xenarthrans. Acta Zool-Stockholm. 90:339-351.

Marshall LG, Cifelli RL. 1990. Analysis of changing diversity patters in Cenozoic land mammal age faunas, South America. Palaeovertebrata. 19:169-210.

McKenna MC, Bell SK. 1997. Classification of mammals. Above the species level. New York (NY): Columbia University Press; p. 1-631.

Mitchell kJ, Scanferla A, Soibelzon E, Bonini R, Ochoa J, Cooper A. 2016. Ancient DNA from the extinct South America giant glyptodont Doedicurus sp. (Xenarthra: Glyptodontiae) reveals that glyptodonts evolved from armadillos. Mol Ecol. 25:3499-3508.

Mones A. 1986. Palaeovertebrata Sudamericana. Catálogo sistemático de los vertebrados fósiles de América del Sur. Parte I. Lista preliminar y bibliografía. -Courier Forschungsinstitut Senckenberg. 82:1-625.

Oliveira EV, Porpino KO, Barreto AF. 2010. On the presence of Glyptotherium in the Late Pleistocene of North-eastern Brazil, and the status of "Glyptodon" and "Chlamydotherium". Paleobiogeographic implications. Neues Jahrb Geol Palaontol. 258:353-363.

Pascual R. 2006. Evolution and geography: the biogeographic history ofSouth American land mammals. Ann Mo Bot Gard. 93:209-230.

Paula Couto C. 1979. Tratado de Paleomastozoologia [Treatise on paleomastozoology]. Rio de Janeiro: Academia Brasileira de Ciencias; p. 590.

Perea D. 2005. Pseudoplohophorus absolutus n. sp. (Xenarthra, Glyptodontidae), variabilidad en Sclerocalyptinae y redefinición de una biozona del Mioceno Superior de Uruguay [Pseudoplohophorus absolutus n. sp. (Xenarthra, Glyptodontidae), viariability in Sclerocalyptinae and redefinition of an upper Miocene biozone in Uruguay]. Ameghiniana. 42:175-190.

Porpino KO, Fernicola JC, Bergqvist LP. 2010. Revisiting the intertropical Brazilian species Hoplophorus euphractus (Cingulata, Glyptodontoidea) and the phylogenetic affinities of Hoplophorus. J Vert Paleontol. 30:911927.

Porpino KO, Fernicola JC, Cruz LE, Bergqvist LP. 2014. The intertropical Brazilian species of Panochthus (Xenarthra, Cingulata, Glyptodontoidea): a reappraisal of their taxonomy and phylogenetic affinities. J V Paleontol. 34:1165-1179.

Pujos F, Salas R. 2004. A Systematic reassessment and paleogeographic review of fossil Xenarthra from Peru. Bulletin de l'Institut Français d'Etudes Andines. 33:331-377.

Pujos F. 2006. Megatherium celendinense sp. nov. from the Pleistocene of the Peruvian Andes and the phylogenetic relationships of Megatheriines. Palaeontology. 49:285-306.

Rabassa J, Ollier C, editors. 2014. Gondwana landscapes in southern South America. Heidelberg: Springer; 545 pp.

Simpson GG. 1945. The Principles of Classification and a Classification of Mammals. B Am Mus Nat Hist. 85:XVI-350.

Soibelzon E, Tonni EP, Bidegain JC. 2008. Cronología, magnetoestratigrafía y caracterización bioestratigráfica del Ensenadense (Pleistoceno inferior-medio) en la ciudad de Buenos Aires [Chronology, magnetoestratigraphybnd biostratigraphic characterization of the Ensenadan (Lower-middle Pleistocene) in the city of Buenos Aires]. Rev As Geol Argentina. 63:421-429.

Soibelzon E, Miño-Boilini AR, Zurita AE, Krmpotic CM. 2010. Los Xenarthra del Ensenadense (Pleistoceno Inferior a Medio) de la Región Pampeana (Argentina) [The Xenarthra from the Ensenadan (lowermiddle Pleistocene) of the Pampean region of Argentina]. Rev Mex Cs Geol. 27:449-469.

Superina M, Loughry WJ. 2015. Why do Xenarthrans matter? J Mammal. 96:617-621.

Tejada-Lara JV, Salas-Gismondi R, Pujos F, Baby P, Benammi M, Brusset S, De Franceschi D, Espurt N, Urbina M, Antoine PO. 2015. Life in Proto-Amazonia: Middle Miocene mammals from the Fitzcarrald Arch (Peruvian Amazonia). Palaeontology. 58:341-378. doi:10.1111/ pala.12147.
Woodburne MO. 2010. The great American biotic interchange: dispersals, tectonics, climate, sea level and holding pens. J Mamm Evol. 17:245264.

Zamorano M. 2012. Los Panochthini (Xenarthra, Glyptodontidae): Sistemática y evolución [The Panochthini (Xenarthra, Glyptodontidae: Systematics and evolution] [Ph. D. thesis]. La Plata, Buenos Aires: Universidad Nacional de La Plata.

Zamorano M. 2013. Diagnosis y nueva descripcion de Propanochthus bullifer (Burmeister) (Xenarthra, Glyptodontidae). Consideraciones bioestratigráficas y cronológicas de su procedencia) [Diagnosis and new description of Propanochthus bullifer (Burmeister) (Xenarthra, Glyptodontidae).Biostratigraphic and chronological considetarions about its origin]. Span. J Paleontol. 28:283-292.

Zamorano M, Brandoni D. 2013. Phylogenetic analysis of the Panochthini (Xenarthra, Glyptodontidae), with remarks on their temporal distribution [Diagnosis and new description of Propanochthus bullifer (Burmeister) (Xenarthra, Glyptodontidae).Biostratigraphic and chronological considetarions about its origin]. Alcheringa. $37: 442-451$.

Zamorano M, Scillato-Yané GJ, Zurita AE. 2013. An enigmatic and largesized pecimen of Panochthus (Glyptodontidae, "Panochthini") from the Ensenadan (Early-Middle Pleistocene) of the Pampean region, Argentina. Rev Mex Biodivers. 84:847-854.

Zamorano M, Scillato-Yané GJ, Zurita AE. 2014. Revisión del género Panochthus Xenarthra, Glyptodontidae) [Revision of the genus Panochthus (Xenarthra, Glyptodontidae)]. Rev Mus La Plata (Secc Paleontol). 14:1-46.

Zamorano M, Oliva C, Scillato-Yané GJ, Ferreira JD, Zurita AE. 2015. Primer registro de Panochthus greslebini Castellanos (Xenarthra, Glyptodontidae, Hoplophorini) para la región Pampeana de Argentina [First record of Panochthus greslebini Castellanos (Xenarthra, Glyptodontidae, Hoplophorini) from the Pampean region of Argentina]. Rev Bras Paleontol. 18:555-564.

Zurita AE. 2007. Sistemática y evolución de los Hoplophorini (Xenarthra, Glyptodontidae, Hoplophorinae. Mioceno tardío-Holoceno temprano). Importancia bioestratigráfica, paleobiogeográfica y paleoambiental [Systematics and evolution of the Hoplophorini (Xenarthra, Hoplophorinae. Late Miocene-Early Holocene). Biostratigraphic, palaeobiogeographic and paleoenvironmental importance] [Ph. D. thesis]. La Plata, Buenos Aires: Universidad Nacional de La Plata.

Zurita AE, Miño-Boilini AR, Soibelzon E, Carlini AA, Paredes-Ríos F. 2009. The diversity of Glyptodontidae (Xenarthra, Cingulata) in the Tarija Valley (Bolivia): systematic, biostratigraphic and paleobiogeographic aspects of a particular assemblage. Neues Jahrb Geol Palaontol. 251/52:225-237.

Zurita AE, Zamorano M, Scillato-Yané GJ, González Ruiz LR, Rivas Durán B, Céspedez Paz R. 2011. An exceptional Pleistocene specimen of Panochthus Burmeister (Xenarthra, Glyptodontoidea) from Bolivia: its contribution to the understanding of the early-middle Pleistocene Panochthini. C R Palevol. 10:655-664.

Zurita AE, Carlini AA, Gillette D, Sánchez R. 2011. Late Pliocene Glyptodontinae (Xenarthra, Cingulata, Glyptodontidae) of South and North America: morphology and paleobiogeographical implications in the GABI. J South Amer Earth Sci. 31:178-185.

Zurita AE, Oliveira E, Toriño P, Rodriguez-Bualó SM, Scillato-Yané GJ, Luna C, Krapovickas J. 2011. On the taxonomic status of some Glyptodontidae (Mammalia, Xenarthra, Cingulata) from the Pleistocene of South America. Ann Paleontol. 97:63-83.

Zurita AE, Miño-Boilini AR, Francia A, Arenas-Mosquera JE. 2012. The Pleistocene Glyptodontidae Gray, 1869 (Xenarthra: Cingulata) of Colombia and some considerations about the South American Glyptodontinae. Rev Bras Paleontol. 15:273-280.

Zurita AE, González Ruiz LR, Gómez-Cruz A, Arenas-Mosquera JE. 2013. The most complete known Neogene Glyptodontidae (Mammalia, Xenarthra, Cingulata) from northern South America: taxonomic, paleobiogeographic and phylogenetic implications. J Vert Paleontol. 33:698-706.

Zurita AE, Toriño P, Cuadrelli F, Medina O, Perea D. 2016. Nuevos registros de Glyptodontinae (Xenarthra, Cingulata, Glyptodontidae) del Altiplano en Bolivia [New records of Glyptodontinae (Mammalia, 
Xenarthra, Glyptodontidae) from the Altiplano of Bolivia]. XXX Jornadas Argentinas de Paleontología de Vertebrados; p. 57.

\section{Appendix 1. List of materials used in this paper for comparative studies and phylogenetic analyses}

Propalaehoplophorus australis: MLP 16-15, MLP 16-16; YMP PU 15212. Glyptodon reticulatus: MCA 2015.

Hoplophorus euphractus: UFMG 1235

Nopachtus cabrerai: MACN-Pv 2670 (holotype).

Nopachtus coagmentatus: MLP 16-122 (holotype).

Panochthus frenzelianus: AMNH 11243 (holotype).

Panochthus greslebini: DGM 1-M (ex SGB 1784 [see Mones 1986, p. 239]) (holotype) and MNRJ 2760.

Panochthus intermedius: MLP 16-36 (holotype) and MHNC-13491.

Panochthus jaguaribensis: MNRJ 2759-V.

Panochthus tuberculatus: MLP 16-29 (neotype), MHGN 633/02 (holotype of Panochthus voghti), MLP $16-37 \mathrm{~b}$ and MPAC s/ $\mathrm{n}^{\circ}$

Panochthus subintermedius: MACN-Pv 5130 (holotype).

Panochthus hipsilis n. sp.: MURB 1906A,B, MHNS, 8

Panochthus cf. P. subintermedius: MLP 84-IX-2-11.

Phlyctaenopyga ameghini: MLP 16-101 (holotype), MLP 29-VIII-8-2 and MLP 29-X-10.

Plohophorus figuratus: MLP 16-153 (holotype).

Propanochthus bullifer: MACN-Pv 1761 (holotype).

Pseudoplohophorus absolutus: FC-DPV-475 and 595 (holotype)

Stromaphorus compressidens MLP 16-138 (holotype), MLP 29-X-8-I and MLP 29-X-8-9.

\section{Appendix 2. List of character and character states used in the cladistic analysis}

1. Presence of a notch in the margins of the narial aperture in lateral view

0 . absent

1. present

2. Position of the roof of the skull respects the upper edge of the orbit. Ratio between the height of the skull roof (over the upper edge of the orbit) and the height of the orbit (modified from Zamorano \& Brandoni 2013)

0 . lower than 0.25

1. between 0.25 and 0.33

2. greater than 0.33

3. Development of postorbital process (modified from Zamorano \& Brandoni 2013)

0. uncomplete postorbital process

1. complete postorbital process

4. Angle between the palatal plane and the plane of rostral area (modified from Zamorano \& Brandoni 2013)

0 . lower than $45^{\circ}$

1. greater than $45^{\circ}$

5. Outline of the orbital notch in lateral view (modified from Zamorano \& Brandoni 2013)

0 . dorso-ventrally elongated

1. subcircular

6. Length of the skull. Ratio between the length of the skull and the height of the skull (regardless of the descendant process of the zygomatic arch) (modified from Zamorano \& Brandoni 2013)

0 . larger than 1.5

1. lesser than 1.5

7. Lachrymal tubercle position (modified from Zamorano \& Brandoni 2013)

0 . the lachrymal tubercle does not protrude the contour of the orbit

1. the lachrymal tubercle protrudes the contour of the orbit
8. Size of the temporal fossa. Ratio between the antero-posterior length of the temporal fossa and the antero-posterior length of the orbit (modified from Zamorano \& Brandoni 2013)

0 . more than 2.5 times the antero-posterior length of the orbit

1. nearly 2 times the antero-posterior length of the orbit

9. Relation between the dorsoventral diameter of the zygomatic arch below the temporal fossa and the dorsoventral diameter below the orbital fossa (modified from Zamorano \& Brandoni 2013)

0 . dorsoventral diameter of the zygomatic arch below the temporal fossa similar to the dorsoventral diameter below the orbital fossa

1. dorsoventral diameter of the zygomatic arch below the temporal fossa almost twice of the dorsoventral diameter below the orbital fossa

10. Orientation of the zygomatic arch (in lateral view) (modified from Zamorano \& Brandoni 2013)

0 . oblique

1. horizontal

11. Cross section of the occipital condyles (modified from Zamorano \& Brandoni 2013)

0 . subcircular

1. subeliptic

2. nearly squared

12. Orientation of the external nostrils (modified from Zamorano \& Brandoni 2013)

0 . anterior

1. antero-ventral

13. Outline of the alveolar edge of the maxillar (modified from Zamorano \& Brandoni 2013)

$0 . \quad$ sigmoid
1. nearly straight

14. Angle formed by the roof of the palate with the alveolar walls (modified from Zamorano \& Brandoni 2013)

0 . obtuse

1. straight

15. Hypsodonty index (expressed as the ratio between the average height of the M6-M8 / the length of the dental series (modified from Zurita 2007)
$0 . \quad 0.57-0.63$
1. $0.50-0.56$
2. $0.43-0.49$

16. Relation between the antero-posterior diameter and the transverse diameter of the M1 (modified from Zamorano \& Brandoni 2013)

0 . almost equal

1. antero-posterior diameter almost twice than the transversal diameter

17. Starts of the trilobulation of the molariforms (modified from Zamorano \& Brandoni 2013)
0 . $\quad$ starts from $\mathrm{M} 3$
1. starts from $\mathrm{M} 2$
2. starts from $\mathrm{M}$

18. Imbrication of the molariforms (modified from Zamorano \& Brandoni 2013)

0 . molariforms imbricated

1. molariforms no imbricated

19. Number of peripheral rows that surround the central figure of the osteoderms of the dorsal region of the dorsal carapace (modified from Zamorano \& Brandoni 2013)
0 . without rows
1. 1-3 rows
2. $4-7$ rows

20. Highest point of the dorsal carapace (modified from Zamorano \& Brandoni 2013)

$0 . \quad$ at the central region

1. at the anterior region 
21. Ornamentation pattern of the osteoderms of the dorsal region of the dorsal carapace
0 . rosette pattern
1. reticular pattern

22. Presence of a central figure in the osteoderms of the anterior region of the dorsal carapace (modified from Zamorano \& Brandoni 2013)

0 . with a central figure

1. without a central figure

23. Morphology of the exposed surface of the osteoderms of the posterior region of the dorsal carapace
0 . with a convex central figure
1. with a flat central figure
2. with a reticular pattern

24. Disposition of the small figures in the osteoderms of the anterior region of the dorsal carapace (modified from Zamorano \& Brandoni 2013)

0 . with a central figure surrounded by $4-7$ rows of peripheral figures

1. with a central figure surrounded by $1-3$ rows of peripheral figures

2. with a complete reticular pattern

25. Disposition of the small figures in the osteoderms of the posterior region pf the dorsal carapace (modified from Zamorano \& Brandoni 2013)

0 . with central figure surrounded by $4-7$ rows of peripheral figures

1. with central figure surrounded by 1-3 rows of peripheral figures

2. with a complete reticular pattern

26. Number of small figures in the first row of the osteoderms of the anterior region of the dorsal carapace (modified from Zamorano \& Brandoni 2013)

0 . less than 12 peripheral small figures

1. more than 12 peripheral small figures

2. without a central figure

27. Number of small figures in the first row of the osteoderms of the posterior region of the dorsal carapace (modified from Zamorano \& Brandoni 2013)

0 . less than 10 peripheral small figures

1. more than 10 peripheral small figures

2. without a central figure

28. Percentage of the exposed surface of the osteoderms of the posterior region of the dorsal carapace occupied by small figures (modified from Zamorano \& Brandoni 2013)

0 . less than $50 \%$

1. more than $50 \%$
29. Morphology of the figures of the anterior and posterior regions of the dorsal carapace

0 . both regions with flat figures

1. posterior region with convex figures and anterior region with flat figures

30. Development of the caudal armor (modified from Zamorano \& Brandoni 2013)

0. caudal armor with caudal tube lesser a $100 \mathrm{~mm}$

1. caudal armor with caudal tube greater a $100 \mathrm{~mm}$

2. caudal armor without caudal tube

31. Central figures in the dorsal region of the caudal tube (modified from Zamorano \& Brandoni 2013)

0 . absent

1. present

32. Morphology of the central figures in the dorsal region of the caudal tube (modified from Zamorano \& Brandoni 2013)
0 . without central figure
1. with smooth central figure
2. with rough central figure

33. Morphology of the distal end of the caudal tube (modified from Zamorano \& Brandoni 2013)
0 . rounded
1. pointed
2. blunt

34. Ornamentation of caudal armor and ornamentation of the dorsal region of the carapace (modified from Zurita 2007)

0 . different ornamentation

1. similar ornamentation

35. Morphology of the central figure of the most proximal row of osteoderms of the caudal tube

0 . smooth surface

1. rough surface

36. Lateral figures of the caudal tube modified in 'spines'

0 . Absent

1. Present

37. Morphology of the exposed surface of the lateral figures of the caudal tube

0 . smooth surface

1. rough surface

\section{Appendix 3. Character-taxon matrix used in the cladistic analysis. Note: ?, missing date}

\begin{tabular}{|c|c|c|c|c|c|c|c|c|c|c|c|c|c|c|c|c|c|c|c|c|c|c|c|c|c|c|c|c|c|c|c|c|c|c|c|c|c|}
\hline Pro. australis & 0 & 0 & 0 & 0 & 0 & 0 & 0 & 1 & 0 & 0 & 1 & 0 & 0 & 1 & 2 & 0 & 0 & 1 & 1 & 0 & 0 & 0 & 0 & 1 & 1 & 1 & 0 & 0 & 0 & 0 & 0 & 0 & 0 & 0 & 0 & 0 & 1 \\
\hline G. reticulatus & 0 & 0 & 0 & 0 & 1 & 0 & 1 & 0 & 0 & 0 & 0 & 0 & 1 & 0 & 2 & 1 & 2 & 1 & 0 & 0 & 0 & 0 & 1 & 1 & 1 & 1 & 1 & 0 & 0 & 2 & 0 & 0 & 0 & 0 & & - & 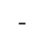 \\
\hline N. coagmentatus & $?$ & $?$ & $?$ & $?$ & $?$ & $?$ & $?$ & $?$ & $?$ & $?$ & $?$ & $?$ & $?$ & $?$ & 7 & $?$ & $?$ & $?$ & $?$ & 0 & 0 & 0 & 0 & 1 & 1 & 1 & 0 & 0 & $?$ & 1 & 1 & $?$ & ? & 1 & $?$ & 1 & 0 \\
\hline N. cabrerai & ? & $?$ & $?$ & $?$ & $?$ & $?$ & $?$ & $?$ & ? & $?$ & $?$ & $?$ & $?$ & $?$ & $?$ & $?$ & $?$ & ? & $?$ & 0 & 0 & 0 & 0 & 1 & 1 & 1 & 0 & 0 & 1 & $?$ & ? & $?$ & & $?$ & & $?$ & \\
\hline Pr. bullifer & ? & $?$ & $?$ & $?$ & $?$ & $?$ & $?$ & $?$ & ? & $?$ & $?$ & $?$ & $?$ & $?$ & $?$ & $?$ & $?$ & $?$ & $?$ & $?$ & 0 & $?$ & 0 & $?$ & 0 & $?$ & 0 & 1 & $?$ & 1 & 1 & 1 & 2 & 1 & 1 & 1 & 1 \\
\hline P. intermedius & 1 & 2 & 0 & 1 & 1 & 1 & 1 & 0 & 1 & 1 & 2 & 1 & 1 & 1 & 2 & 1 & 2 & 1 & 1 & 0 & 1 & 0 & 1 & 0 & 0 & 1 & 0 & 1 & 0 & 1 & 1 & 2 & & 1 & 1 & 1 & \\
\hline P. tuberculatus & 1 & 2 & 1 & 1 & 1 & 1 & 1 & 0 & 1 & 1 & 2 & 1 & 1 & 1 & 2 & 1 & 2 & 1 & 2 & 1 & 1 & 1 & 2 & 2 & 2 & 2 & 2 & 1 & 0 & 1 & 1 & 2 & 2 & 1 & 1 & 1 & 1 \\
\hline P. subintermedius & 1 & 1 & 0 & $?$ & 0 & 1 & $?$ & 0 & 0 & 0 & 1 & 1 & 0 & 0 & 0 & 0 & 1 & 0 & $?$ & 1 & 1 & 1 & 2 & 2 & 2 & 2 & 2 & 1 & 0 & 1 & 1 & 2 & 1 & 1 & 1 & 1 & 1 \\
\hline P. greslebini & $?$ & $?$ & $?$ & $?$ & $?$ & $?$ & $?$ & $?$ & $?$ & $?$ & $?$ & $?$ & $?$ & $?$ & $?$ & $?$ & $?$ & $?$ & $?$ & $?$ & 1 & 1 & 2 & 2 & 2 & 2 & $?$ & 1 & 0 & 1 & 1 & 2 & 1 & 1 & 1 & 1 & 1 \\
\hline P. hipsilis n. sp. & 1 & $?$ & 1 & 1 & 1 & 1 & 1 & 0 & 1 & $?$ & 2 & 1 & 1 & 1 & $?$ & 1 & 2 & 1 & $?$ & 1 & 1 & 1 & 1 & 2 & 2 & 2 & 0 & 1 & 0 & 1 & 1 & 2 & $?$ & 1 & 1 & 1 & 1 \\
\hline Pl. figuratus & 0 & 1 & 0 & 0 & 1 & 0 & 1 & 0 & 0 & 0 & 2 & 0 & 1 & 1 & 2 & 0 & 1 & 1 & $?$ & 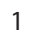 & 0 & 0 & 1 & 1 & 1 & 1 & & 0 & & 1 & 1 & 1 & 2 & 1 & 0 & 0 & 0 \\
\hline Ps. absolutus & 0 & 1 & 0 & 0 & 1 & 0 & 1 & 0 & 0 & 0 & 2 & 0 & 1 & 1 & 2 & 0 & 1 & 1 & 0 & 1 & 0 & 0 & 1 & 1 & 1 & 1 & 1 & 0 & 0 & 1 & 1 & 1 & 2 & 1 & 0 & 0 & 0 \\
\hline S. compressidens & 0 & 1 & 0 & 0 & 1 & 0 & 0 & 0 & 0 & 1 & 2 & 0 & 0 & 1 & 1 & 0 & 1 & 1 & $?$ & 1 & 0 & 0 & 0 & 1 & 1 & 0 & 0 & 0 & 1 & 1 & 1 & 1 & 2 & 1 & 0 & 0 & 0 \\
\hline Ph. ameghini & 0 & 1 & 0 & 0 & 1 & 0 & 1 & 0 & 0 & 0 & 2 & 0 & 1 & 1 & 2 & 0 & 1 & 1 & 0 & 0 & 0 & 0 & 0 & 1 & 1 & 0 & 0 & 0 & 1 & 1 & 1 & 1 & 2 & 1 & 0 & 0 & 0 \\
\hline H. euphractus & 0 & 2 & 0 & 0 & 1 & 0 & 1 & 0 & $?$ & $?$ & 2 & 0 & 1 & $?$ & 2 & $?$ & $?$ & $?$ & $?$ & 0 & 0 & 0 & 1 & 1 & 1 & 1 & 0 & 0 & 0 & 1 & 1 & 1 & 2 & 1 & 0 & 1 & 1 \\
\hline N. ornatus & 0 & 2 & 0 & 0 & 0 & 1 & 1 & 0 & 0 & 1 & 2 & 0 & 1 & 1 & 2 & 1 & 1 & 1 & 1 & 0 & 0 & 0 & 1 & 1 & 1 & 1 & 0 & 0 & 0 & 1 & 1 & 1 & 0 & 1 & 0 & 0 & 0 \\
\hline
\end{tabular}

